\title{
Function of Production, Capital, Labor and Government Policy in The Coal Mining Sector - Case Study of an Indonesian Coal Mining Company
}

\author{
${ }^{1}$ Suryadi $^{a}$, Yeni Nuraeni ${ }^{\mathrm{b}}$, Ivan Lilin Suryono ${ }^{\mathrm{c}}$, Yuniarti Tri Suwadji ${ }^{\mathrm{d}}$, \\ Hennigusnia $^{\mathrm{e}}$, Nur Siti Annazahf, Zelius Ragilliawang, a,b,c,d,e,f,g Policy \\ Development Center, Ministry of Manpower, Email: \\ asuryadi.value@gmail.com, byeninur@hotmail.com, civanlilins@gmail.com, \\ dyuniartits85@gmail.com, \\ f anazah.siti@gmail.com, ${ }^{\mathrm{g}}$ zellius.ragiliawan@gmail.com
}

This study aims to determine the effect of labor, capital, and government policies on coal output and the scale of coal business results of PT Indo Tambangraya Megah Tbk. The new thing from this research is the Cobb-Douglas production function which usually uses labor and capital variables, but in this study, it has been expanded by adding policy variable in the form of Law No. 4 of 2009 regarding Mineral and Coal Mining, which is not yet present in other studies. The research method is linear regression using the Cobb-Douglas model function. The results showed that labor did not significantly influence coal production. Capital has a significant effect on model 2 and policy has a significant effect on model 3 . The coal mining business of PT Indo Tambangraya Megah Tbk is in decreasing return to scale because if the three variables are combined, it will be worth -0.24 . This condition occurs because the additional output produced is smaller than the additional input ( $\delta \%$ output $<\delta \%$ input).

Key words: Cobb Douglas, Law No.4 of 2009, Decreasing Return to Scale

\footnotetext{
${ }^{1}$ All the writers are main contributors.
} 


\section{Introduction}

Indonesia is one of the world's coal producers and exporters. Indonesia's coal reserves are expected to be exhausted in the next 83 years if the current production levels continue. There are many pockets of coal reserves found in Indonesia, however, there are three provinces with the largest coal reserves, namely South Sumatra, South Kalimantan, and East Kalimantan. Since the beginning of 1990, when the coal mining sector was reopened for foreign investment, Indonesia experienced an increase in domestic coal production, exports and sales.

At present, the use of coal for domestic consumption is still small (Table 1). In the range 20182019 , it is estimated that there will be a rapid increase in domestic coal sales because the government has committed to using coal as an energy source since Indonesia has enough coal reserves. In addition, several large mining companies have expanded into the energy sector. The company is an integrated energy company that consumes their own coal.

Table 1. Coal Production, Export and Consumption in Indonesia (Million Tonnes)

\begin{tabular}{|l|c|c|c|c|c|c|}
\hline & $\mathbf{2 0 1 4}$ & $\mathbf{2 0 1 5}$ & $\mathbf{2 0 1 6}$ & $\mathbf{2 0 1 7}$ & $\mathbf{2 0 1 8}$ & $\mathbf{2 0 1 9}$ \\
\hline Production & 458 & 461 & 456 & 461 & $425^{1}$ & $400^{1}$ \\
\hline Export & 382 & 375 & 365 & 364 & $311^{1}$ & $160^{1}$ \\
\hline Domestic & 76 & 86 & 91 & 97 & $114^{1}$ & $240^{1}$ \\
\hline
\end{tabular}

Source: Indonesian Coal Mining Association and Ministry of Energy and Mineral Resources, $2020{ }^{1)}$ Projection figure

Coal is an important and most economical source of energy according to Ocal et al. (2013). Coal consumption in Turkey does not show a causal relationship to the economy. Energy conservation policies can be adopted without affecting Turkish economy. Policy makers need to explore the feasibility of reducing or increasing the efficiency of coal consumption. Different results occur in India, coal consumption to reduce carbon emissions in turn has an impact on economic growth (Anhal, 2013). Dependence on future energy needs in India on coal must be reduced. The most important implication is that limiting coal consumption to reduce carbon emissions will in turn have limited economic growth.

The Government of Indonesia's policy has greatly influenced the national coal mining industry. To obtain domestic supply, the Ministry of Energy and Mineral Resources asks coal producers to reserve a certain amount of production for domestic consumption. In addition, the Government can regulate its export taxes to reduce coal exports. Over the past few years, the Government of Indonesia has expressed a desire to increase domestic consumption of coal so that coal supplies about $30 \%$ of the national energy mix in 2025 (Table 2). 
International Journal of Innovation, Creativity and Change. www.ijicc.net

Volume 15, Issue 9, 2021

Table 2. Indonesian Energy Mix

\begin{tabular}{|l|c|c|}
\hline & $\begin{array}{c}\text { Energi Mix } \\
\mathbf{2 0 1 1}\end{array}$ & $\begin{array}{c}\text { Energi Mix } \\
\mathbf{2 0 2 5}\end{array}$ \\
\hline Crude Oil & $50 \%$ & $23 \%$ \\
\hline Coal & $24 \%$ & $30 \%$ \\
\hline Natural Gas & $20 \%$ & $20 \%$ \\
\hline Renewable Energy & $6 \%$ & $26 \%$ \\
\hline
\end{tabular}

Source: Ministry of Energy and Mineral Resources, 2014

According to Santra and Bagaria (2014), coal is one of the main sources of energy which accounts for about $67 \%$ of total energy consumption in India. There is no doubt that labor productivity in the coal mining sector has increased since 1951 . However, the increase in labor productivity in the coal mining sector is due to increased productivity in Orissa and Tamil Nadu. On the other hand, the study of Ogujiuba et al. (2014) supports economic theory in the Cobb-Douglas Function specification. They recommended that the government continue to maintain reforms in the mining sector and continue to strengthen institutions, transparency, accountability, and improve governance.

The coal sector is a mainstay for Indonesia in supporting economic growth and employment. This is also evident from the still high interest in investment in the mining sector. This condition occurs because there are still abundant coal resources owned by Indonesia. An increase in investment both from domestic and foreign, is expected to increase employment absorption.

The large number of people working in the mining sector is largely determined by the demand for the sector's output. The resulting output is very much determined by the coal production function, so that it needs to be managed properly for all resources to run properly. Workers need to be regulated because they have their own backgrounds, abilities, and shortcomings; therefore, their performance becomes more effective and efficient. Resources need to be regulated because the numbers are limited, in order to produce optimal output.

The company needs a business strategy to achieve optimal production. PT Indo Tambangraya Megah Tbk is a company engaged in coal mining. To face increasingly competitive business competition, business strategy planning for companies is one solution that can help them in achieving company targets. Table 3 shows some of the strengths, weaknesses, opportunities and threats faced by the company. Although PT. Indo Tambangraya Megah Tbk faces a variety of threats, but the company has good internal strength, especially in staffing to anticipate these threats by maximizing the existing strength in utilizing the various opportunities that exist. The company must always be aware of the development of the main competitors and minimize internal weaknesses. 
As a mining company, PT Indo Tambangraya Megah plays a role in opening up employment opportunities for Indonesian workers (national, regional and local) as well as opportunities to acquire mining knowledge in more depth, because mining companies are capital intensive and relatively skilled in skilled workers. Coal as one of the abundant energy sources in Indonesia, contributes quite a lot to the economic progress in Indonesia. This potential has made many coal mining companies stand in Indonesia. The characteristics of the coal mining industry are capital-intensive mining companies, meaning that they require a large amount of capital for the mining company's needs, for example heavy equipment, transportation, employee salaries.

Table 3. Internal and External Factors at PT Indo Tambangraya Megah Tbk.

\begin{tabular}{|c|c|}
\hline Internal Factors & External Factors \\
\hline $\begin{array}{l}\text { Strengths } \\
\text { - Have competent employees } \\
\text { - Has many subsidiaries, also known as sites } \\
\text { - Have a good relationship with customers } \\
\text { and other external parties } \\
\text { - Use information technology in every } \\
\text { activity in the company }\end{array}$ & $\begin{array}{l}\text { Opportunities } \\
\text { - The use of coal is still rare } \\
\text { - Alternative fuel trends (other than oil and } \\
\text { natural gas) } \\
\text { - Coal as a more environmentally friendly } \\
\text { fuel }\end{array}$ \\
\hline $\begin{array}{l}\text { Weaknesses } \\
\text { - Dominated by older workers } \\
\text { - Annual reports that are often late } \\
\text { - Existing information or data tends to not } \\
\text { detail even a lot of data duplication. }\end{array}$ & $\begin{array}{l}\text { Threats } \\
\text { - The emergence of a coal company similar } \\
\text { to PT. Indo Tambangraya Megah, Tbk } \\
\text { - Increased operational production costs } \\
\text { - Changes in foreign exchange rates } \\
\text { - Decreased service \& product quality } \\
\text { - Complex price \& business competition } \\
\text { - Government policies on mining and trade } \\
\text { - Fraud committed by employees }\end{array}$ \\
\hline
\end{tabular}

Sources: Saiydah Zainab, Olivia Andry and Nyoman Laksono Bayu Aji, Binus University, 2012

Coal mining is a non-renewable natural resource that is controlled by the state and its use is used for the greatest prosperity of the people. Therefore, the management of coal mines must add value to the national economy.

Related to this, the government continues to make efforts to encourage business players to improve themselves and make breakthroughs so as to increase the added value of Indonesian coal to a position that can prosper the people and determine for world trade. The good intentions of the government in the effort to encourage the business actors referred to are contained in Law No. 4 of 2009 concerning Mineral and Coal Mining, where the basic material contained 
in this Law regulates the downstreaming of mineral and coal mining products and prohibits the export of raw materials from 2014.

As a result of the enactment of Law No. 4 of 2009, nationally there has been a massive increase in exports in the last 3 years. The law has regulated the obligations for processing and refining mines and minerals which are imposed no later than 5 (five) years since the Act was enacted on January 12, 2009 so that the enforcement of processing and refining of mines and minerals fell in January 2014.

Law No. 4 of 2009 mandates the construction of smelters so that domestic mining production can be processed before being exported. The purpose of the Mineral and Coal Law is intended, so that Indonesia can obtain added value from mining and mineral products so that it can boost gross domestic product and absorb labor.

This research aims to:

a. Analysing the effect of labor, capital and government policies on coal output of PT Indo Tambangraya Megah Tbk.

b. Analysing the scale of the operations results of PT Indo Tambangraya Megah Tbk.

The hypotheses tested are:

$\mathrm{H}_{0}: \mathrm{Bn}=0$ (Variable input of labor, capital and government policy does not significantly influence the coal output of PT Indo Tambangraya Megah Tbk.)

$\mathrm{H}_{1}: \mathrm{Bn} \neq 0$ (Variable input of labor, capital and government policy significantly influence the coal output of PT Indo Tambangraya Megah Tbk.)

The new thing from this research is the cobb douglas production function which usually uses labor and capital variables, but in this study it has been expanded by adding a policy variable that is the influence of law No. 4 of 2009 concerning Mineral and Coal Mining, which is not yet present in other studies. In general, micro-scale research only focuses on the relationship of input and output within a company. Policy variables are included in the production function to determine the effect of the policy on coal production in the company PT Indo Tambangraya Megah Tbk. Several studies that have included the effect of labor variables and other inputs on coal production, among others, were conducted by Betz et al. (2014), Jamli (2012) on the effect of investment and labor on coal production and economic growth in Kutai Kartanegara, Pennsylvania Economy League (2014) on The Economic Impact of the Coal Industry in Pennsylvania and Energy in the theory of production (Pokrovski, 2002). 


\section{Literature Review}

In 1928, C.W.Cobb and P.H. Douglas created and described production functions that were widely used in various branches of industry. The model they present, is very good for estimating the production process and its results. Rybak (2019) conducted a study with a sample of coal companies in Poland because the characteristic of the mining industry in Poland is the high level of environmental diversity. Therefore, his research aims to find effective analytical and strategic planning tools in diverse environments.

The production function is a function that shows the maximum number of outputs that resulted from certain input combinations. The production function in neo-classical theory is: $Y=f(C$, $\mathrm{L})$. The assumption of the production function uses two factors, namely capital (C) and labor (L). The production function is constant returns to scale or if all factors of production are proportionally increased, the output will increase in the same proportion. So changes in output are affected by changes in capital and changes in labor. The company pays the production factor by providing capital and labor costs or wages that become income for workers.

Capital is one of the most important factors of production for mining businesses (Atteridge, 2018). An international perspective on the global coal market will affect the allocation of capital in the coal mining sector in the future. Capital is the availability of cash in the form of cash or can also mean wealth owned by a company that can generate profits in the future and is expressed in monetary value. Capital is the company's wealth expressed in the form of money used for the production process in order to obtain profits in the future.

Cobb-Douglas function is a function or equation that involves two or more variables (Suryadi, 2013). One variable is called the dependent variable, that is the variable described (Y) and the other variables are referred to as variables independent, that is the variable that explains $(\mathrm{X})$. The equation of the Cobb-Douglas production function is:

$\mathrm{Y}=\mathrm{f}(\mathrm{C}, \mathrm{L}$,

Where:

Y: output,

C: capital

L: labor

The production curve or TP is a curve that shows the relationship of total production with one variable input while the other inputs are considered constant.

$\mathrm{TP}=\mathrm{f}(\mathrm{X})$ 
Where:

TP : total production / total output,

$\mathrm{X}$ : input variable

The average production curve is a curve that shows the average output per unit of input at various levels of use of these inputs. To find out the average production is as follows :

$\mathrm{APx}=\frac{\mathrm{TP}}{\mathrm{X}}=\frac{\mathrm{Y}}{\mathrm{X}}$

Marginal product to measure how much additional output is produced if a variable input increases by one unit while the other inputs are fixed. Mathematically can be written:

$\operatorname{MPx}=\frac{\partial T P}{\partial X}=\frac{\partial Y}{\partial X}$

Production elasticity (Ep) is the percentage change in output as a result of the percentage change in input. The output elasticity of inputs is defined as:

$\mathrm{Ep}=\frac{\left(\frac{\partial \mathrm{Y}}{\partial \mathrm{x}}\right)}{\left(\frac{Y}{X}\right)}$ atau $\mathrm{Ep}=\frac{(\mathrm{MP})}{(\mathrm{AP})}$

The elasticity of output to input is the ratio between marginal productivity and the average production of inputs. In this case there are three possible conditions, namely:

1. Elasticity is smaller than one, or Ep $<1$, if and only if (MP) $<(\mathrm{AP})$.

2. Elasticity is equal to one, or $\mathrm{Ep}=1$, if and only if $(\mathrm{MP})=(\mathrm{AP})$.

3. Elasticity is greater than one, or Ep> 1, if and only if (MP)> (AP).

The elasticity is elastic if the value is more than one, which means that if the input of production factors changes, the output will change with a percentage exceeding the percentage change in the input. Elasticity is inelastic if the elasticity value is between zero and one, with the percentage change in input of production factors greater than the change in output produced.

Return to scale consists of three concepts, namely:

\section{Constant Return to scale}

This condition occurs if the additional output produced is the same as the additional input ( $\delta \%$ output $=\delta \%$ input). 


\section{Increasing Return to scale}

This condition occurs when the additional output produced is greater than the input $(\delta \%$ output $>\delta \%$ input).

\section{Decreasing Return to scale}

This condition occurs when the additional output produced is smaller than the additional input ( $\delta \%$ output $<\delta \%$ input).

The main material contained in Act No. 4 of 2009 concerning Mineral and Coal Mining, which regulates the mining of mineral, coal, and bans the export of raw materials until 2014 (PricewaterhouseCoopers, 2018). Therefore, this Act mandates construction of a smelter so that domestic coal production can be processed before being exported. The purpose of the Act is so that Indonesia can produce added value from coal products so that it can improve the economy and absorb labor. This came into effective in January 2014 for metal mineral mining commodities, nonmetallic minerals and coal.

Furthermore, the government issued Government Regulation (PP) No. 23 of 2010 on February 1, 2010 concerning the Implementation of Mineral and Coal Mining Business Activities. This regulation requires that holders of Mining Business Licenses (IUP) for production operations and Special Mining Business Permits (IUPK) for production operations must prioritize coal needs for domestic interests. Furthermore, in order to provide greater opportunities for Indonesian participants to participate more in mineral and coal mining business activities and in order to provide legal certainty for holders of Contracts of Work and Coal Mining Concession Work Agreements who intend to extend in the form of Mining Business Permits, then issued PP No . 24 of 2012 concerning Amendments to Government Regulation Number 23 of 2010 concerning Implementation of Mineral and Coal Mining Business Activities.

\section{Research Methods}

In this study, the researchers used the secondary data collected from PT Indo Tambangraya Megah Tbk in 2004-2018. The analysis used is inference analysis using multiple linear regression models. The model will explain the relationship between the independent variable $(\mathrm{X})$ and one independent variable (Y). The purpose of inferencing analysis is to find out the factors that have a significant influence on the coal production of PT Indo Tambangraya Megah Tbk during the period 2004-2018.

The model used by the researchers in analyzing the relationship between coal production inputs and outputs is the Cobb-Douglas production function model. The Cobb-Douglas function is a function or equation that involves two or more variables. One variable is referred to as the 
dependent variable, namely the explained variable (Y) and the other variableS are referred to as the independent variable, i.e the explaining variable (X). Mathematically, the function can be written in the following equation:

$\mathrm{Y}=\mathrm{aX} \mathrm{X}_{1}^{\mathrm{b} 1} \mathrm{X}_{2}^{\mathrm{b} 2} \mathrm{X}_{3}^{\mathrm{b} 3}$

and if the function is lineared, it will become:

$\log Y=\log a+b_{1} \log X_{1}+b_{2} \log X_{2}+b_{3} \log X_{3}+\ldots \ldots+u$

An explanation of the variables from the above equation is:

$\mathrm{Y}=$ total coal production (million tons) in 2004-2018

$\mathrm{X} 1$ = capital obtained by means of assets - liabilities (million US \$)

$\mathrm{X} 2$ = number of workers (people)

X3 = government policy, dummy variable (value 0 for before 2009 and 1 after 2009)

$\mathrm{a}=$ intersept

bi $=$ estimator regression coefficients $\left(b_{1}, b_{2}\right.$ and $\left.b_{3}\right)$

$\mathrm{u}=$ residual

$\log =\log$ arithm

The linear Cobb-Douglas production function can be used to analyze the independent variables that affect coal output variables. The above equation uses multiple linear regression analysis with the Ordinary Least Square (OLS) method. From this model, it can be seen the elasticity value of each input $(\mathrm{Xi})$ to output $(\mathrm{Y})$. The input elasticity is reflected by the coefficient of rank or the parameter value of the model.

\section{Results and Discussion}

From the results of the single regression equation in Table 4, it is known that the capital and policy variables significantly influence the creation of coal output of PT Indo Tambangraya Megah Tbk. While the labor variable has no significant effect on the creation of company output. To improve the performance of its employees so that they have a positive influence, companies need to encourage employees to achieve competence optimally so that they can encourage the company to achieve prosperity and success. The recruitment system needs to consider work experience and educational background. Workers need to be involved to participate in aligning their individual targets with the company's strategic goals and periodically evaluated.

The human resources division needs to make training and development plans that are designed according to the needs of the company's organization current and future organizations. Formal 
training needs to be focused on key areas that aim to improve managerial, operational and employee behavior skills. For senior management, development plans that need to be continued include leadership and entrepreneurship. The development plan for middle management needs to be improved on professional knowledge and human resource management. Technical knowledge and continuous improvement need to be provided to professional and operational staff.

Table 4. Regression Coefficient of a Single Test

\begin{tabular}{|c|c|c|c|c|c|c|c|c|}
\hline \multicolumn{2}{|c|}{ Model } & \multicolumn{2}{|c|}{$\begin{array}{l}\text { Unstandardized } \\
\text { Coefficients }\end{array}$} & \multirow{3}{*}{$\begin{array}{l}\text { Standardized } \\
\text { Coefficients } \\
\text { Beta } \\
\\
.828\end{array}$} & $\mathrm{~F}$ & $\mathrm{R}^{2}$ & $\mathrm{t}$ & Sig. \\
\hline \multirow{2}{*}{1} & (Constant) & 692 & 122 & & \multirow[b]{2}{*}{$28.309 * *$} & \multirow[b]{2}{*}{.685} & $5672 * *$ & 000 \\
\hline & $\log X 1$ & .235 & .044 & & & & $5.321 * *$ & .000 \\
\hline \multirow[t]{2}{*}{1} & (Constant) & 3.216 & 1.944 & & \multirow[b]{2}{*}{$.938 \mathrm{~ns}$} & \multirow[b]{2}{*}{.067} & $1.655 \mathrm{~ns}$ & .122 \\
\hline & $\log X 2$ & -.541 & .559 & -.259 & & & $-.968 \mathrm{~ns}$ & .351 \\
\hline \multirow[t]{2}{*}{1} & (Constant) & 1.206 & .029 & & \multirow[b]{2}{*}{$29.351 * *$} & \multirow[b]{2}{*}{.693} & $41.576 * *$ & .000 \\
\hline & X3 & .192 & .036 & .832 & & & $5.418^{* *}$ & .000 \\
\hline
\end{tabular}

Source: Data Processed, 2020

Note: ** Very significant, ns (not significant)

Furthermore, the researchers conclude that the capital variable as shown in Table 5 has a significant effect on the creation of the coal mining output of PT Indo Tambangraya Megah Tbk. The capital variable is inelastic because its value is less than one. Every 1 percent increase in capital will increase the volume of coal by 0.23 percent. In economic theory, the basic assumption regarding the nature of the production function is that the production function is subject to a law called the additional law of diminishing returns. This law says if one type of input is added while the other inputs are fixed, then the additional output produced from each additional one input unit added earlier increases but then continues to decrease if the input continues to be added.

Coal mining requires a large capital including costs for land acquisition, infrastructure development and operational costs. Capital can come from own capital or loan capital in running the company's production process. Own capital in the form of cash, savings, securities, houses, land, vehicles, jewelry and metals, receivables. Business capital from other parties in the form of other people's money (joint ventures), personal loans in the form of money or assets, loans from banks, venture capital, advances, trade debts, stock exchanges, credit card utilization. 
International Journal of Innovation, Creativity and Change. www.ijicc.net

Volume 15, Issue 9, 2021

Table 5. Coefficient of Multiple Regression Between Variables of Capital and Labor

\begin{tabular}{|c|c|c|c|c|c|c|c|c|}
\hline \multirow{2}{*}{\multicolumn{2}{|c|}{ Model }} & \multicolumn{2}{|c|}{$\begin{array}{c}\text { Unstandardized } \\
\text { Coefficients }\end{array}$} & \multirow{2}{*}{$\begin{array}{l}\text { Standardized } \\
\text { Coefficients } \\
\text { Beta }\end{array}$} & \multirow[t]{2}{*}{$\mathrm{F}$} & \multirow[t]{2}{*}{$\mathrm{R}^{2}$} & \multirow[t]{2}{*}{$\mathrm{t}$} & \multirow[t]{2}{*}{ Sig. } \\
\hline & & B & Beta & & & & & \\
\hline \multirow[t]{3}{*}{2} & (Constant) & 1.024 & 1.255 & & \multirow{3}{*}{$13.178 * *$} & \multirow{3}{*}{.687} & $.816 \mathrm{~ns}$ & .431 \\
\hline & $\log X 1$ & .232 & .048 & .816 & & & $4.876 * *$ & .000 \\
\hline & $\log X 2$ & -.093 & .349 & -.045 & & & $-.266 \mathrm{~ns}$ & .795 \\
\hline
\end{tabular}

Source: Data Processed, 2020

Note: ** Very significant, ns (not significant)

If the three variables consisting of capital, labor and policies are processed together as in Table 6 , it will be seen that only policy variables that have a significant effect on coal production output of PT Indo Tambangraya Megah Tbk. The company's management believes that there will be a significant positive impact with the policy in the form of Mining Law No. 4/2009. Very important in the new policy related to the implementation of coal mining activities in Indonesia is the obligation to build mineral processing and refining facilities in the country no later than January 2014.

Many business people objected to the policy and considered that this policy would reduce the trade balance of the mining sector in Indonesia. A number of business actors then renegotiated and even one of the business actors sued the government. However, this policy is the best for improving the mineral mining sector in the long run so that Indonesia is no longer known as an exporter of mineral resources but as a country that is able to provide added value.

As a business activity, the researchers conclude that the coal mining industry is a capital intensive (high capital), high risk (high risk), and high technology (high technology) intensive industry. In addition, the coal mining business also depends on natural factors that will affect the location where the mineral reserves are. Mineral and coal mining business activities contain economic value, starting from the effort to determine the position, area, amount of reserves, and geographical location of land containing minerals and coal. After the existence of reserves is discovered, the exploitation (production), transportation, and other supporting industries will have a very high economic value so that business competition will open in the series of industries. In 2018, the company will again develop its business through the acquisition of $100 \%$ of PT Nusa Persada Resources (NPR) shares. The NPR concession is currently not operational and it is located in Central Kalimantan. This acquisition provided an increase in coal reserves of 77 million tons. 
International Journal of Innovation, Creativity and Change. www.ijicc.net

Volume 15, Issue 9, 2021

Table 6. Coefficient of Multiple Regression Between Variables of Capital, Labor and Policy

\begin{tabular}{|c|c|c|c|c|c|c|c|c|}
\hline \multirow{2}{*}{\multicolumn{2}{|c|}{ Model }} & \multicolumn{2}{|c|}{$\begin{array}{c}\text { Unstandardized } \\
\text { Coefficients }\end{array}$} & \multirow{2}{*}{$\begin{array}{l}\text { Standardized } \\
\text { Coefficients } \\
\text { Beta }\end{array}$} & \multirow[t]{2}{*}{$\mathrm{F}$} & \multirow[t]{2}{*}{$\mathrm{R}^{2}$} & \multirow[t]{2}{*}{$\mathrm{t}$} & \multirow[t]{2}{*}{ Sig. } \\
\hline & & B & Beta & & & & & \\
\hline \multirow[t]{4}{*}{3} & (Constant) & 2.634 & 1.257 & & \multirow{4}{*}{$\begin{array}{c}14.178 \\
* *\end{array}$} & \multirow{4}{*}{.795} & 2.096 & .060 \\
\hline & $\log X 1$ & .071 & .078 & .250 & & & .907 & $\begin{array}{c}.384 \\
\mathrm{~ns}\end{array}$ \\
\hline & $\log X 2$ & -.458 & .332 & -.219 & & & -1.377 & $\begin{array}{c}.196 \\
\mathrm{~ns}\end{array}$ \\
\hline & X3 & .147 & .061 & .638 & & & 2.398 & $.035 *$ \\
\hline
\end{tabular}

Source: Data Processed, 2020

Note: ** Very Significant, $*$ Significant, ns (not significant)

From the data processed, the researchers found that the coal mining business of PT Indo Tambangraya Megah Tbk is in a decreasing return to scale because if the three variables are combined, it will be worth -0.24 . This condition occurs because the additional output produced is smaller than the additional input ( $\delta \%$ output $<\delta \%$ input). To increase the role of labor and capital in coal output, companies need to continue to do good things that have been done at this time such as making investment policies by preparing IT infrastructure and human resources that are ready to adapt to change. Transformation and digitalisation that never stops along the supply chain, is the answer for the company in responding to the challenges and changes that exist, to achieve corporate sustainability.

Companies need to continue to explore information from various stakeholders to receive input from the community, central and local governments, customers, the media, non-governmental organizations and workers. Relevant issues need to be mapped based on direct dialogue with stakeholders to foster good relations through effective communication. Thus, the company will be able to make improvements, as well as know the needs and expectations of all stakeholders.

In general, we also suggest that companies need to make digital investments, introduce new corporate cultures, plan development and community empowerment activities and establish departments of the Digital Center of Excellence and Corporate Social Responsibility (CSR) departments. All changes are implemented to keep abreast of business developments and create added value for all stakeholders. 


\section{Conclusion}

From the results of a single regression equation, the researchers found that capital and policy variables significantly influence the creation of coal output of PT Indo Tambangraya Megah Tbk. While the labor variable has no significant effect on the creation of company output.

Through the multiple regression equation that is by processing capital and labor variable data together, the researchers found that the capital variable has a significant effect on the creation of coal mine output and is inelastic because its value is less than one. Every 1 percent increase in capital will increase the volume of coal by 0.23 percent. Labor variable does not significantly affect the coal output of PT Indo Tambangraya Megah Tbk.

By processing all three variables consisting of capital, labor and policy together, the researchers conclude that only policy variables that have a significant effect on the coal production output of PT Indo Tambangraya Megah Tbk. In addition, the coal mining business of PT Indo Tambangraya Megah Tbk is in a decreasing return to scale, and when the three variables are combined, it will be worth -0.24 . The researchers examine that this condition occurs because the additional output produced is smaller than the additional input ( $\delta \%$ output $<\delta \%$ input).

\section{ACKNOWLEDGEMENT}

The researchers thank to Policy Development Center, Ministry of Manpower for the kindly support in conducting this research. 
International Journal of Innovation, Creativity and Change. www.ijicc.net

Volume 15, Issue 9, 2021

\section{REFERENCES}

Anhal, R. (2013), Causality between GDP, Energy and Coal Consumotion in India, 19702011 : A Non-parametric Boostrap Approach. Internasional Journal of Energy and Policy: 3(4) pp.434-446.

Atteridge, A., Aung, M. T., Nugroho, A. (2018), Contemporary coal dynamics in Indonesia. Working Paper. Stockholm Environment Institute.

Betz, M., Farren, M., Lobao, L., Partridge, M. D. ( 2014), Coal Mining, Economic Development, and the Natural Resources Curse. http://mpra.ub.uni-muenchen.de/58016/ Jamli, (2012), Pengaruh Investasi dan Tenaga Kerja Terhadap Produksi Batubara dan Pertumbuhan Ekonomi di Kutai Kartanegara (The Influence of Investment and Labor on Coal Production and Economic Growth in Kutai Kartanegara). Jurnal Eksis : 8(2) pp. $2168-2357$.

Kecojevic, V., Grayson, R.L. (2008), An Analysis of the Coal Mining Industry in the United States. Mineral \& Energy : 23(2) pp.74-83.

Ocal, O., Ozturk, I., Aslan, A. (2013), Coal Consumption and Economic Growth in Turkey. Internasional Journal of Energy and Policy : 3(2) pp.193-198.

Ogujiuba, K., Adebayo, F., Stiegler, N. (2014), Efficiency of Capital-Labor in Nigeria's Mining Sector: A Cobb-Douglas Framework. Journal of Economics and Behavioral Studies : 6(9) pp.760-770.

Pennsylvania Economy League (2014), The Economic Impact of the Coal Industry in Pennsylvania. Pittsburgh, Pennsylvania.

Pokrovski, V.N. (2002), Energy inThe Theory of Production. doi:10.1016/S03605442(03)00031-8 www.elsevier.com/locate/energy.

PricewaterhouseCoopers (2018), Mining in Indonesia Investment and Taxation Guide. www.pwc.com.

Rybak, A. (2019), Application of The Cobb-douglas Production Function to Study The Results of The Production Process and Planning Under Turbulent Environment Conditions. doi: 10.24425/gsm.2019.128529 www.journals.pan.pl

Santra, S., Bagaria, N. (2014), Labour Productivity in Coal Mining Sector in India : With Special to Major Coal Mining States. https://mpra.ub.uni-muenchen.de/53519/

Suryadi (2013), Production Function and Preparation of the Economic and Environmental Balance of Tin Resources in Indonesia. Jurnal Teknologi Mineral dan Batubara : 9(3) pp. $135-144$. 